\title{
Desert loess: a selection of relevant topics
}

\author{
Ian Smalley ${ }^{1 *}$, John Marshall ${ }^{2}$, Kathryn Fitzsimmons ${ }^{3}$, W. Brian Whalley ${ }^{4}$, \\ Samson Ngambi ${ }^{1}$
}

\author{
${ }^{1}$ Centre for Research in the Built \& Natural Environment, Coventry University, Coventry CV1 5FP, UK (I.S. - \\ ijsmalley@gmail.com, S.N. - apx290@coventry.ac.uk) \\ 2SETI Institute. Mountain View, CA 94043, USA (j.marshall@seti.org) \\ ${ }^{3}$ Research Group for Terrestrial Palaeoclimates, Max Planck Institute for Chemistry, 55128 Mainz, Germany \\ (K.Fitzsimmons@mpic.de) \\ ${ }^{4}$ Department of Geography, University of Sheffield, Sheffield S10 2TN (B.Whalley@Sheffield.ac.uk) \\ ${ }^{*}$ corresponding author, e-mail: ijsmalley@gmail.com
}

\begin{abstract}
In discussions on loess, two types are often demarcated: glacial loess and desert loess. The origin of the idea of desert loess appears to lie with V.A. Obruchev who observed wind-carried silt on the Potanin expedition to Central Asia in 1895. It might be considered that desert loess would be defined as loess associated with deserts but it came to be thought of as loess produced in deserts. This led to some controversy as no mechanism for producing silt particles in deserts was readily available. Bruce Butler in Australia in particular cast doubt on the existence of desert-made loess.

Butler indicated loess-like deposits in Australia which he called Parna; these are very like loess but the silt sized particles are actually clay mineral agglomerates of silt size- formed in dry lake regions.

At the heart of the desert loess discussion is the problem of producing loess material in deserts. It has been suggested that there are no realistic mechanisms for forming large amounts of loess dust but there is a possibility that sand grain impact may produce particle shattering and lead to the formation of quartz silt. This would appear to be a reasonable mechanism for the African deposits of desert loess, but possibly inadequate for the huge deposits in China and Central Asia. The desert loess in China and Central Asia is loess associated with a desert. The material is formed in cold, high country and carried by rivers to the vicinity of deserts. It progresses then from deserts to loess deposit.

Adobe ground may be defined as desert loess. Adobe occurs on the fringe of deserts, notably in the Sahelian region of Africa, and in SW USA. The use of adobe in construction represents the major utilization of desert loess in a social context. More understanding of adobe is required, in particular with respect to the adobe reaction, the low order chemical reaction which provides modest cementitious properties, and can be likened to the pozzolanic reactions in hydrating cement systems.

The location of loess and loess-like ground on the peripheries of deserts is aided by the observation of the nesting sites of bee-eater birds. These birds have a determined preference for loess ground to dig their nesting tunnels; the presence of nest tunnels suggests the occurrence of desert loess, in desert fringe regions.

We seek amalgamation and contrast: ten main topics are considered: words and terms, particles, parna, geotechnical, adobe, people, birds, Africa, Central Asia, Mars. The aim is some large generalizations which will benefit all aspects of desert loess investigation.
\end{abstract}

Key words: Parna, adobe, silt formation in deserts, large dust \& small dust, Martian deserts, bee-eaters nesting in loess

"But my real interests were far away. Always I saw two men in the hot glens of the Oxus, with the fine dust of the loess rising in yellow clouds behind them." John Buchan 'The Power House'

"Too large a generalization leads to mere barrenness. It is the large generalization, limited by a happy particularity, which is the fruitful conception."

A.N. Whitehead 'Science and the Modern World'. 


\section{Introduction}

In their study of the onset of aridification across the Eocene-Oligocene transition in Central Asia, Sun \& Windley (2015) made a passing reference to theories of loess formation: "The most common hypotheses for the formation of loess are glacial loess and desert loess. According to the former, glacial grinding plays an important role by producing great quantities of silt sized materials necessary for the formation of thick loess deposits (Smalley 1966). ... The desert loess hypothesis was suggested by Obruchev (1911) to explain nonglacial mechanisms of silt production by eolian abrasion in deserts."

This is essentially the default status for theories of loess formation, although the statement by Sun \& Windley is somewhat misleading. Obruchev was not producing alternatives to glacial grinding but suggesting desert specific mechanisms for loess material production. A problem with desert loess proposals was that they required loess material to be produced in desert regions by desert specific processes. Obruchev (1911) is the generally accepted initiation of the study of 'desert' loess.

Put 'desert loess' into Google Scholar; 70,000+ hits are produced in a few seconds. The top reference is Tsoar \& Pye (1987), with 500+ citations. This can be seen as a starting point for a study of the concept of desert loess, and a history of its development.

"Although contemporary dust storms are reported to be frequent in arid and semi-arid areas ... desert loess deposits are poorly developed in comparison with those found in mid-latitudes. The reasons for this have been much discussed but remain poorly defined. Much of the debate has focussed on whether sufficient silt is produced by weathering and other processes in warm deserts (Smalley \& Vita-Finzi 1968, Kuenen 1969)" (Tsoar \& Pye, 1987, p.140).

A brief semantic excursion is required; the concept of 'desert loess' has come to mean loess which has been produced in a desert. This appears to be the basic Obruchev idea that the loess dust is made in the desert by desert processes. It might be better to refer to 'loess associated with deserts' so that deserts can contain and store loess dust and have loess deposits around the perimeters - which can be called desert loess. This dichotomy should be recognized; we need to be aware of all usage which can cause confusion.

The second reference on the Google Scholar desert loess list is Smalley \& Vita-Finzi (1968). This paper posed the critical problem of finding a desert mechanism that could produce silt sized loess material. And, considering the vast extent of, say, the Chinese loess, this would need to be a very effec- tive and efficient mechanism capable of delivering vast volumes of material. This was the setting of the problem: can loess material be produced in deserts? Smalley \& Vita-Finzi cited observers such as Penck (1930) and Butler (1956) who had failed to find desert loess in desert regions and had suggested that no efficient desert based mechanism existed.

The third paper on the Google Scholar list is Heller \& Liu (1982). Here some bibliographic manoeuvring is required and some corrections have to be emplaced. The small quotation accompanying the Heller \& Liu entry relates to loess in China:

"We also suggest that much of this material from many deserts has been deposited in the sea but that the Chinese loess could have been produced in the Gobi desert." This looks like a serious endorsement of a desert source for the Chinese loess - actually the quotation is not from the Heller \& Liu paper, which, in fact, has no direct connection to desert loess. The quotation is a critical statement from Whalley et al. (1982). Confusion has obviously arisen from the fact that parts of the Heller \& Liu and Whalley group papers had appeared on the same page in the relevant issue of Nature. The Whalley group material had been wrongly assigned to the Heller \& Liu paper. The Whalley group paper should be third on the desert loess listing. This presents a convincing case for the production of silt by aeolian impact via laboratory experiments, and led on to a whole series of studies on desert loess possibilities (Wright, 1995, 2001a, 2001b, 2007; Wright et al., 1998; Wright \& Smith, 1993; Smith et al., 2002).

The purpose of this review is to consider desert loess in all its aspects. This will require identification of the different approaches to the topic of desert loess and the recognition of fields of study where desert loess might be relevant. Also a few hitherto unasked questions might be raised; the most striking question is whether it was realised that of the four Soviet institutes set up to study hydrocollapse in loess, three concentrated on glacial loess but one (in Tashkent) actually focussed on desert loess. Were any contrasts actually made? The basic idea is that we may achieve mutual benefit; bee-eater nest sites may relate to adobe construction; particle formation in terrestrial deserts may relate to particle formation in the deserts of Mars; a close look at desert material may reveal interesting facts about the size modality of terrestrial sediments.

\section{Obruchev was the first}

We may place the beginning of the desert loess story with Obruchev (Fig.1) in Tomsk. His expe- 


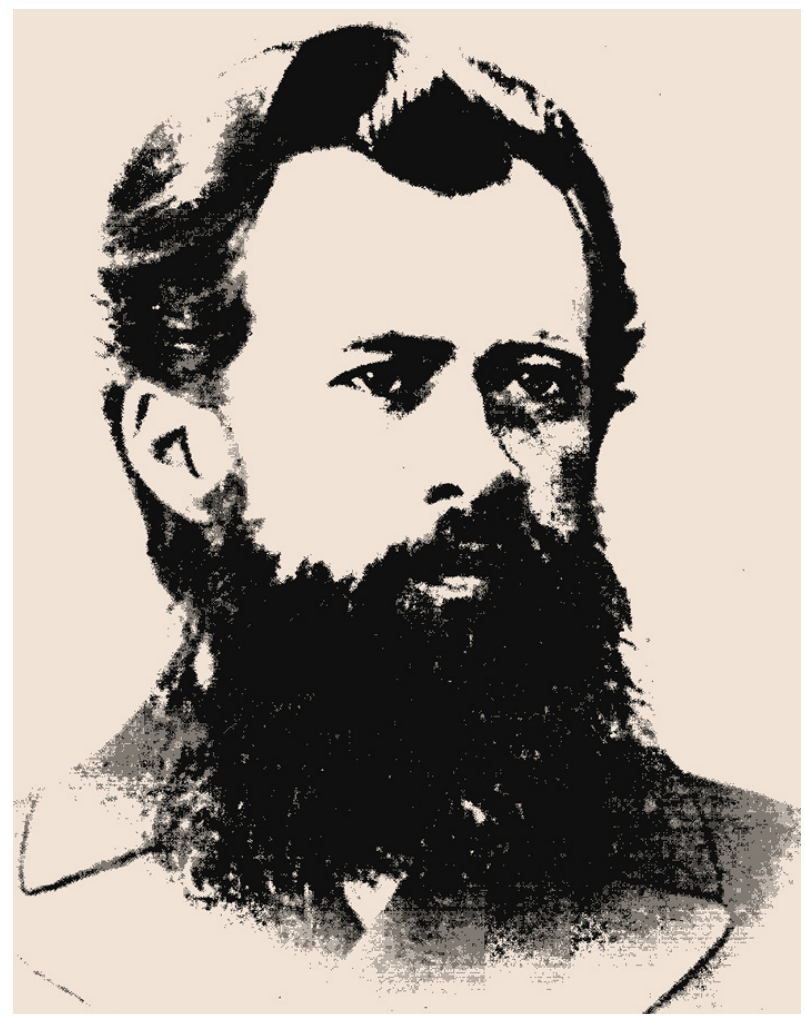

Fig. 1. Vladimir Afanas'evich Obruchev (1863-1956). The photo from the beginning of the $20^{\text {th }}$ century; the Tomsk years, the invention of desert loess. He was the 'onlie begetter' of desert loess

riences and observations in Central Asia, particularly as part of the Potanin expedition (see Smalley \& Markovic, 2018a), led him to the conclusion that loess and deserts were closely associated. The obscure 1911 publication was made internationally famous by a commentary from Merzbacher (1913) which placed this work firmly in the foundations of the study of loess history. No alternative seminal work has ever been proposed, so Obruchev (1911) initiates the study of desert loess.

"He [Obruchev] comes to the conclusion that, firstly, the loess dust in its overwhelming measure is a product of the weathering and disintegration processes in the desert. Whether hot or cold, stony, clayey or sandy, small or large, no matter whether they are complete, without vegetation or in the manner of dry steppes, are covered with sparse vegetation, which, however, is unable to protect the soil adequately against the action of the wind." (translated from Merzbacher, 1913, p. 16).

\section{Australia and the parna problem}

Large hot deserts are located in Australia; given the deserts there might be desert loess. But one of the

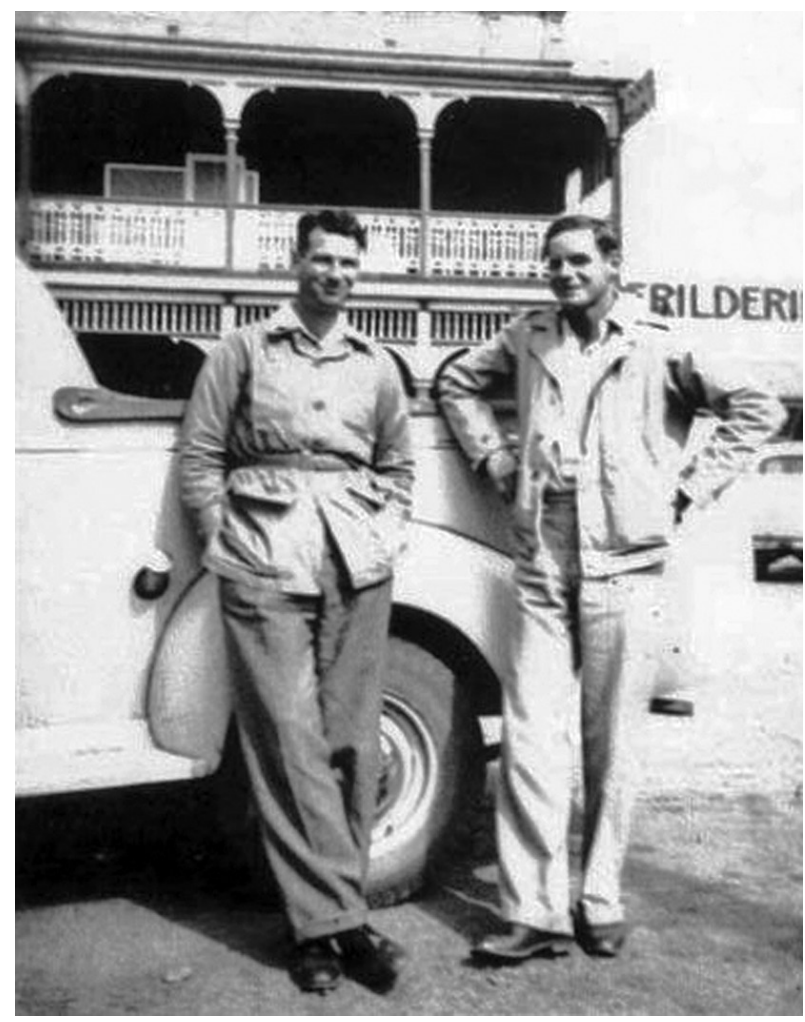

Fig. 2. Roy Brewer (left) and Bruce Butler of CSIRO at Jerilderee NSW in 1947. Both offered important ideas relevant to the study of desert loess

key statements in the desert loess story was made by Bruce Butler (Fig. 2) with respect to Australian deserts and it cast doubt on the whole desert loess project.

"The comparatively trivial extent of the Pleistocene glaciations on the mainland of Australia... would not suggest any extensive areas of loess of the 'cold' type. There is more plausibility in expecting sheets of 'hot' loess, since deserts make up a large proportion of the Australian landscape. ... Indeed, considering the vast area of deserts in the world, and our relative ignorance of 'hot' loess, the latter may be more hypothetical than real. ... There has recently been discovered and studied a material which, in the Riverina Plain of south-eastern Australia, lies as a sheet covering the whole landscape irrespective of relief." (Butler, 1956, p. 145). Butler was describing a deposit which he named 'parna' which is remarkably like default loess, except that the silt-sized primary mineral particles are replaced by silt-sized clay mineral agglomerate particles.

Haberlah $(2007,2008)$ and Smalley (2008) discussed the Australian loess. Haberlah wished to establish that loess investigation had an Australian relevance and argued cogently that parna should be considered as loess, or as a loess equivalent. This appears to be a reasonable conception and has in 


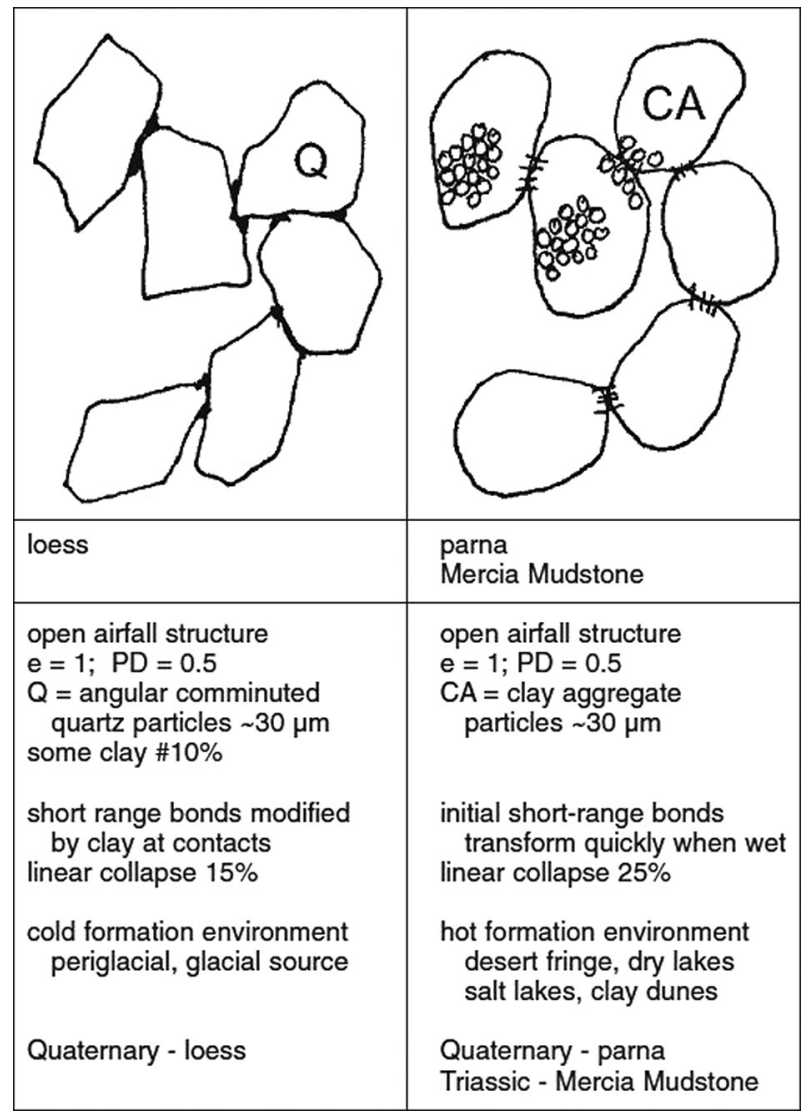

Fig. 3. Mercia Mudstone. A suggested comparison between loess and parna; there are many similarities (Jefferson et al., 2002). Triassic parna relates well to Quaternary parna, which is very like loess

fact been explored in the unlikely context of the Mercia Mudstone in the English Midlands by Jefferson et al. (2002) (Fig. 3). A Triassic parna in Leicestershire is probably much like a Quaternary parna in New South Wales in Australia. It has been suggested that there might be parna-like deposits on Mars (Greeley \& Williams, 1994). There have been comparisons of Earth and Mars from a loessic point of view (Smalley \& Krinsley, 1978) but the Martian deserts suffer from the same handicap as terrestrial deserts - there is no apparent way of making loess sized particles, hence Mars lacks major loess deposits. Mars lacks loess deposits for the same reason as the Sahara region lacks loess deposits; it's the old particle formation question.

Had desert loess investigation started in Australia parna would be the default deposit. It is a silt-sized airfall deposit, it mantles the landscape in a truly loessic manner, and it entrains climatic and environmental information. More detailed studies are available.

"Eolian clay deposits are widespread in Australia. These were first recognised by Hills (1939) who reported the occurrence of dunes on the eastern shores of many relict lakes in western Victoria built of eolian clay. As a result of their crescentic shape, he termed the dunes lunettes (Hills, 1940). Soon after this other workers recognised calcareous clay sheets widespread over the South Australian landscape (e.g. Crocker, 1946). However it was Butler (Butler, 1956; Butler \& Hutton, 1956) who first organised the evidence for eolian clay deposits into a coherent framework, suggested a mechanism for their formation, and coined a new term to describe them: Parna." (Dare-Edwards, 1983, p. 4).

Both Haberlah (2007) and Dare-Edwards (1983, 1984) have suggested incorporating parna within the definition for loess such that parna is essentially loess. There is materials based counter argument: loess and parna are both airfall deposits of silt sized particles but in the case of loess the particles are essentially primary mineral fragments, in the case of parna the particles are clay mineral agglomerates it seems worthwhile to sustain the distinction.

\section{Yaalon's investigations of Sinai loess}

Dan Yaalon, in Israel, should be noted as a significant contributor to scholarly action on the topic of desert loess; he was close to desert loess and actively promoted its interests, and deserves an early mention.

Yaalon (1969) veered towards the Obruchev vision of desert loess. In his terse and precise statement for the $6^{\text {th }}$ INQUA Congress in Paris he placed desert loess as a material formed in desert regions: "The gradient of decreasing particle size and thickness from the loessial desert fringe region is one of the factors which point to the Sinai desert as the major provenance of the eolian material. Additional dust could be brought in from the more distant North African deserts. ... Studies in the Sinai desert show that silt and clay size material is obtained in the desert by the disintegration and weathering of pre-existing sedimentary rocks. ... It is suggested that desert loess of the Central Asian and the Gobi deserts originated in a similar sequence of processes." (Yaalon, 1969, p. 755).

\section{African loess regions}

Figure 4 is a map of Africa from Crouvi et al. (2010) which indicates their location of desert loess deposits across the continent. They put modest desert loess deposits in Africa and nearby regions: "In Africa, the Middle East and Arabia there are seven recognised and well known loess deposits, in Israel, 


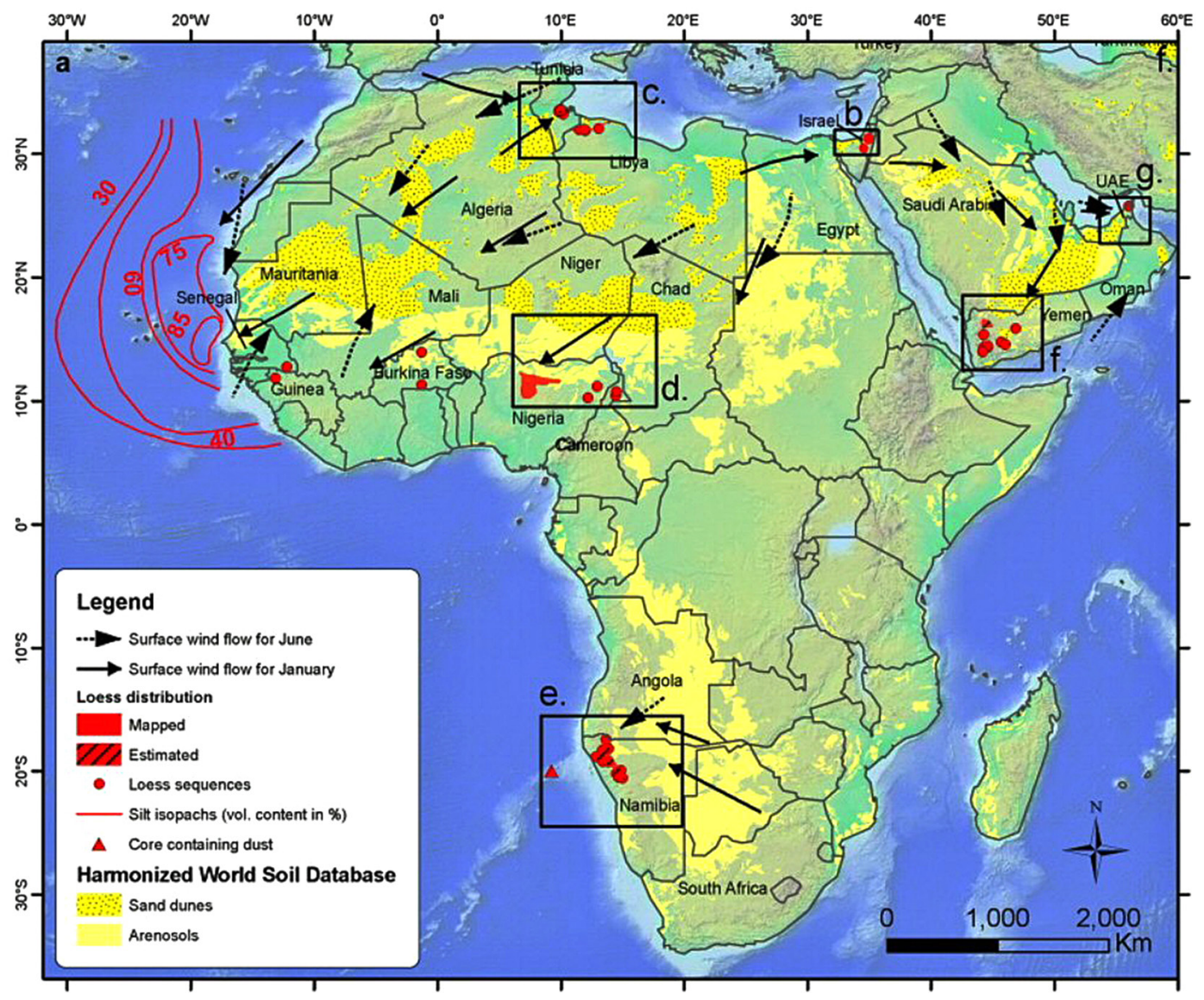

Fig. 4. Desert loess in Africa - a distribution of minor deposits demarcated by Crouvi et al. (2010)

Tunisia, Libya, Nigeria, Namibia, Yemen, and the UAE." (Crouvi et al., 2010, p. 2087).

Crouvi et al. (2008) provided a close study of sand dunes as major proximal dust sources for late Pleistocene loess in the Negev desert. These studies by the Crouvi group (Crouvi et al., 2008, 2010) offer a detailed examination of material in Africa and adjacent regions and a careful allocation of sources and distribution modes. They favour a particle impact production mechanism for quartz silt particles.

"The hypothesis that silt grains can form in warm deserts, through aeolian abrasion of sand particles that subsequently form loess deposits was suggested by Smalley \& Vita-Finzi (1968)." (Crouvi et al., 2010, p. 2090).

The region of the Negev has been much studied and a valuable and informative guidebook has been published which gives remarkably detailed reports of the loess in this region of Israel (Crouvi et al., 2015).

\section{Large dust and small dust}

The desert loess discussion was, for some time, troubled by the failure to realise that there are two types of silt which need to be recognised. Crouvi et al. (2010) made this point very clearly: "A distinction between coarse $(20-63 \mu \mathrm{m})$ and fine $(2-20 \mu \mathrm{m})$ silt grains is important because coarse silt grains are only transported short distances $(<300 \mathrm{~km})$ through saltation and short term suspension." (Crouvi et al., 2010, p. 2092).

This point was made by Stuut et al. (2009) - the need to recognise large dust and small dust. The more significant scientific fact is that the supply of clastic particles to ground materials is essentially bimodal. Breakdown of crustal rocks tends to favour the production of sand and silt. Geochemical forces predetermine the sizes of sedimentary particles (Smalley, 1966; Smalley \& Markovic, 2018b). Coarse silt $=$ large dust is produced by the breakdown of the crustal eutectic quartz which is controlled by the introduction of Moss defects via the high-low crystalline transition in quartz. Actually focussing on quartz may allow three modes to be distinguished. There is a sand mode (say at about $300 \mu \mathrm{m})$ which is controlled by the operation of a eutectic-like reaction in the original crustal granites and which delivers a well marked mode size, sand is universal because granite is universal. The quartz 
in the source rocks undergoes a high-low crystalline transformation which causes tensile stresses to develop which control the size of eventual silt particles; more universal geochemistry leads to universal silt (say around $30 \mu \mathrm{m}$ - one order of magnitude down from sand). Two very well marked modes exist, and these might be supplemented by another; much less well defined - at around $3 \mu \mathrm{m}$, yet another order of magnitude down. These are the particles (perhaps a special name is required) which are produced in sandy regions in great sandy deserts. A feasible impact mechanism has been proposed (see O'Hara-Dhand et al., 2010) which can produce these very small particles; the intrinsic stress in the sand particles, augmented by the modest impact stresses causes very small surface spallation and the formation of a very fine impact mode. Very fine dust in sandy deserts is carried in high suspension for long distances. The important fact about these three size modes is their very modality. Each mode has a defined formation mechanism; there is not a continuity of particle size. This very fine dust is the material indicated by Stuut et al. (2009) as blowing out of the more western regions of the Sahara.

\section{China and Central Asia - key to resolve the loess source}

Penck (1930), in his generalizations about Central Asia, briefly discussed the formation of loess deposits: "Central Asia owes its dry areas to the nival and subnival climate of its roof; all derive their water from the melting of snow or glaciers. Their feeding by rain or springs is insignificant. In spring or in summer they are fullest, during the winter feeble. They bring water into the arid region and carry with themselves from the high regions enormous quantities of debris which they deposit in the form of alluvial fans at the foot of the mountains. They have a freight of sand and mud which accompanies them until they disappear. This freight is then seized by the wind which blows the sand into dunes and carries away the mud in the form of dust. ... Richthofen has the great merit of having recognized loess as an aeolian deposit. But it has not its origin in the decomposition of the rocks of deserts or steppes; it comes like the sand of many dunes from river deposits which are rearranged by the wind..." (Penck, 1930, p. 545).

The loess deposits of China and Central Asia are derived from the mountains of 'High Asia' (Stevens et al., 2013; Li et al., 2018). The High Asia situation has a very high, very large, region supplying many

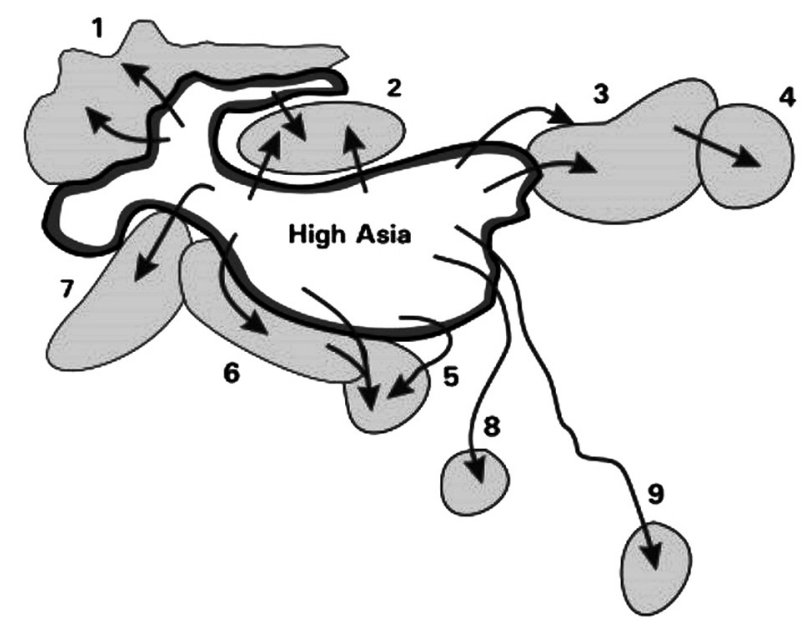

Fig. 5. Rivers carrying silt out of High Asia. Some of these rivers are major carriers of desert loess material. This is the Penckian picture. 1 - Central Asian loess; 2 - Tarim basin loess; 3 - North China loess; 4 - North China alluvial plain, made of re-deposited loess after many 'events' (Smalley \& Krinsley, 1978); 5 - Ganges-Brahmaputra delta; 6 - North India alluvium; 7 - Indus alluvium; 8 - Irrawaddy delta; 9 - Mekong delta

rivers (Fig. 5) with water and clastic material, in a truly Penckian fashion. The great deposits of 'desert' loess are supplied by High Asia. The loess in Tajikistan started its story with the mountain glaciers of High Asia. Penck (1909) was very clear that the Sahara deserts were not associated with any significant loess deposits.

\section{Adobe - from brick to loess problem}

Adobe is a much used but little studied building material. Adobe deposits are associated with desert regions and buildings made from adobe bricks are constructed by desert fringe communities using what is essentially desert loess material. This is a difficult area of investigation, there are significant terminological problems, and adobe ground has never been significantly mapped, and the adobe $=$ desert loess identity has not been properly discussed.

The word adobe comes from the Arabic at-tub meaning mud brick. It was carried into southern Spain (Andalus) and incorporated into Spanish and then travelled to the New World. Actually the word comes from ancient Egyptian via Coptic to Arabic; it is an old word from an old world (2000 BC). The word is used in various non-specific ways and may mean a building or style of building made from adobe ground materials. Adobe ground makes adobe bricks which make adobe buildings. It is the adobe ground which concerns us here, largely because adobe appears to be a variant of desert loess. Ado- 


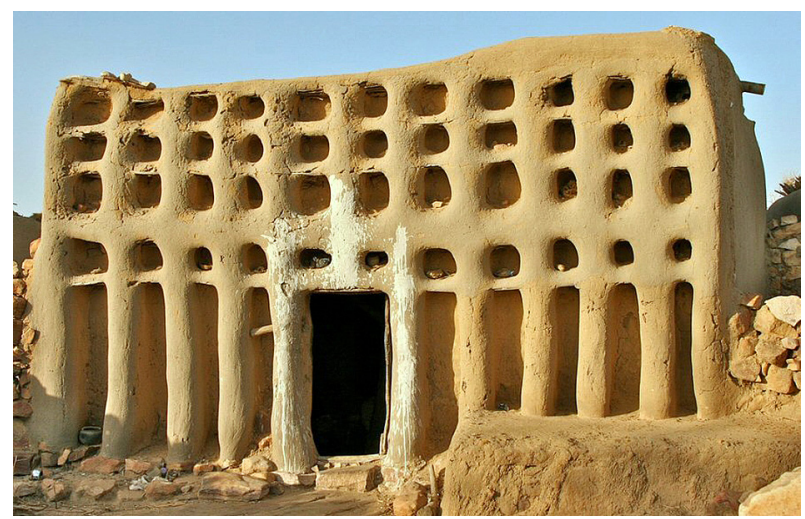

Fig. 6. Adobe buildings - a 'gina' (highouse) of the Dogon people of Mali (Sangha, Mali), built with Sahelian adobe

be is a desert fringe material and adobe buildings shelter people in desert fringe communities. The southern fringe of the Sahara desert is classic adobe country and the great adobe buildings are found in this region (see Fig. 6).

Adobe ground is mixed with water and makes adobe bricks, which are air dried. In the adobe/ water system a low order chemical reaction develops, the so-called adobe reaction (Rogers \& Smalley, 1995). This reaction is like the pozzolanic reaction which adds strength in hydrating Portland cement systems. Normal cement hydration produces a calcium silicate hydrate which delivers cementing properties. Also produced is by-product lime. This lime can be reacted with added siliceous materials to produce a modest, but useful, addition to the strength of the system. The Romans used pozzolanic mortars and these have aided in the longevity of Roman structures. In the adobe system silica particles react with depositional carbonates, via the added water to produce a calcium silicate hydrate cementing system. Little is known about this reaction, all analytical signals are very weak, but local builders have learnt to make stable and attractive structures.

The sources of the adobe in the Sahel probably lie in the Great Sandy Desert to the north but there could be contributions from the low mountains to the west and the Nile regions to the east. The river Niger may be a more significant supplier of adobe material than has been recognized. The adobe in SW USA likewise has a nearby desert and also connections to the Colorado river which is able to supply silty material from the southern end of the Rocky Mountains. The desert + river combination may be important for the supply of adobe material to adobe ground.

In his seminal study of the engineering properties of loess Scheidig (1934) referred to adobe, and melded it with desert loess: "In addition to the aforementioned loesses, which are mainly of glacial origin, there are continental loesses in the fringe regions around desert and steppe zones. Keilhack (1920) mentions this in Texas, Shaler (1899) in Montana, Henning (1911) in Colorado, New Mexico and Arizona.

In the latter two areas, the loess is closely related to the formation known as 'adobe' (pronounced adobi) in fact; in most cases it is identical to adobe." (translated from Scheidig, 1934, p. 52).

Adobe bricks are often called mud bricks, but a rather pedantic, yet important, distinction needs to be made here. Adobe bricks are not technically mud bricks. Mud bricks are made from mud which contains a certain proportion of clay mineral material. The mud bricks owe their properties to the combination of clay mineral materials and water. The negatively charged clay mineral particles, the presence of dissolved cations in the ground water, and the polarised nature of that ground water lead to the mass we call mud. The physical action of drying concentrates particle contact numbers and strength develops. The adobe reaction is altogether more complex. It does not involve clay minerals; it is a true low-order chemical reaction which produces weak cementing forces. It depends on the nature of the adobe ground, a silty ground with a significant amount of quartz particles, plus a modest amount of carbonate material, in a dry environment.

The pozzolanic reaction in a hydrating cement system depends on the interaction of by-product lime with added siliceous material in an aqueous environment. In the adobe reaction the ground supplies the siliceous particles, and some carbonate; wetting and mixing provide the aqueous environment and the slow reaction develops. In adobe buildings the adobe reaction can continue for a long time and gives additional strength and durability to the structure. This is the essential philosophy of the use of pozzolanic materials in concrete structures; long term strength is improved (Rogers \& Smalley, 1995).

\section{Geotechnical problems}

By far the most important geotechnical problem associated with loess ground is that of hydroconsolidation and subsidence. The open structure of loess ground collapses when loaded and wetted and this may cause problems for foundations and other engineering structures. There is a vast literature on subsidence problems, and since most of these problems occurred within the boundary of the old Soviet Union, they are in Russian. The So- 
viet Government set up four research centres to tackle subsidence problems; these were in Moscow, Kiev, Dnepropetrovsk and Tashkent. The loess in the west of the Soviet Union was definitely not desert loess, but the loess in the Tashkent region most probably was. The great scholar of subsidence in the loess around Tashkent was G.A. Mavlyanov (e.g. Mavlyanov, 1958) and the work is carried on in independent Uzbekistan.

The loess in Libya has been examined from a geotechnical perspective (Assallay et al., 1998) and characteristic subsidence behaviour revealed in a series of oedometer tests. Further studies on the loess in North Africa have been undertaken by Rahmani et al. (2018) and they have developed the initiatives of Assallay et al. (1998).

\section{Bee-eaters in the loess}

In Europe the European Bee-eater (Merops apiaster) nests in tunnels which it excavates into loess deposits (Smalley et al., 2012). It has a particular preference for loess because loess ground fits almost exactly to the requirements of the 'Heneberg compromise'. This is the statement that the nesting

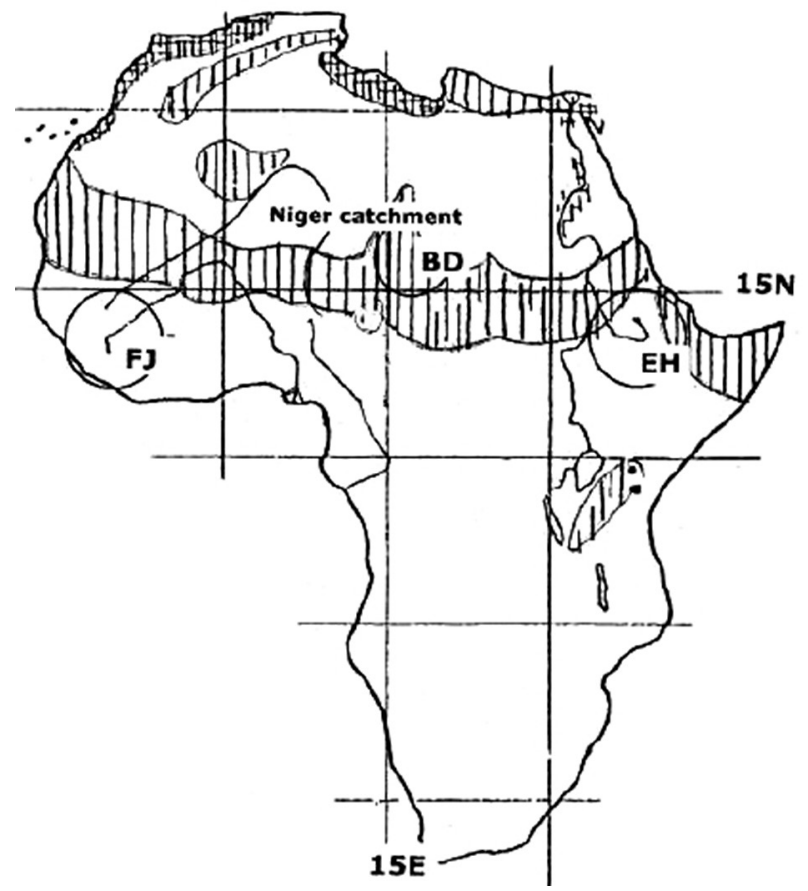

Fig. 7. Bee-eaters in Africa. The Sahelian region is favoured by bee-eaters and provides useful building material. The indicated sources could provide large and small dust. Some possible sources of particles for desert loess: FJ - Fonta-Djalon highlands; BD - Bodele depression; EH - Ethiopian Highlands, catchment of River Niger ground must offer the right combination of strength and excavateablity; loess is good in this respect, so the birds identify and use loess deposits - almost to the exclusion of other types of ground material. In Europe there is abundant loess, but in other parts of the world the loess is not so abundant, or so well defined.

The nesting behaviour of the Northern Carmine Bee-eater (Merops rubicus) in Africa was examined (McLaren et al., 2014) and this showed a concentration of sites in the Sahelian region (Fig. 7). The behaviour of this particular bee-eater certainly indicated the presence of loess-like ground to the south of the Sahara.

The Australian bee-eater or Rainbowbird (Merops ornatus) also indicates the presence of suitable nesting ground in the south-east of the country (Smalley et al., 2012, 2016). This is an interesting observation because of the lack of verified sightings of loess in Australia (Butler, 1956). But the birds indicate the presence of ground which has properties resembling loess and which provides suitable nesting sites. This is desert loess or material which might be defined as such.

\section{Martian deserts}

Mars has deserts and dust. Considering the extent of the desert terrain and its physiographical longevity it is surprising that there is not more dust, and perhaps some substantial loess deposits. It seems likely that Mars lacks a mechanism for forming the Martian equivalent of large dust. Dust is formed by impact on Mars but this is an inefficient mechanism and little material is produced, and very fine dust is favoured. Smalley \& Krinsley (1978) considered the Martian loess situation, relative to the Earth, but that was largely speculation. There are now some solid facts emerging which give a more considered picture of the nature of dust on Mars and its likely place of origin (Ojha et al., 2018). The impressive study by Ojha et al. (2018) contained a studied comparison with some loess investigations: "Early terrestrial work suggested glacial grinding to be the only natural process that efficiently converted sand-sized (0.06-2 $\mathrm{mm}$ diameter) quartz particles into silt-sized $(<62.5 \mu \mathrm{m})$ product (e.g. Smalley \& Krinsley, 1978). In more recent years, a number of other mechanisms, such as frost shattering, fluvial comminution, volcanism, aeolian abrasion, and salt weathering, have been proposed to account for dust deposits that occur near arid or semi-arid regions where glaciers have not existed (Derbyshire et al., 1998; Wright et al., 1998; Wright, 2001; Whalley et 
al., 1982). ... The relative effectiveness of these various silt-producing mechanisms has been investigated in laboratory settings (Wright et al., 1998)." (Ojha et al., 2018, p. 2867).

\section{Discussion}

There were several controversies related to desert loess. Penck (1930) and Butler (1956) cast doubts on its existence, certainly as a significant deposit. Smalley \& Vita-Finzi (1968) raised the question of the availability of a desert-specific mechanism which could produce silt particles. But Obruchev (1911) had specified a mechanism to produce 'hot' loess, and the idea of two types of loess 'hot' and 'cold' grew popular in the world of loess scholarship.

When Julius Fink was establishing the INQUA Loess Commission and organising the study of loess he tended to favour an elaborate descriptive system (in particular for the INQUA Loess Map of Europe) in which many types of loess were recognised (see Smalley, 1975, p. 5) e.g. Berg loess, Hangloess, Fliessloess, Schwemmloess, Gleyloess etc.) - these were descriptive terms, used against a soil science background. As terms for types of loess they were not popular, but Russell (1944) was very insistent that descriptive terms for loess should be just that descriptive, no hint of formation mechanism should be in the classifying term. A different view would be to make the mechanism of formation part of the loess term, as in glacial loess, or desert loess - a step into proper geomorphology. We have a situation now where four sensible types of loess term might be considered: (a) glacial loess produced by ice-sheets, i.e. much of the North American loess, much of the SW Russian and Ukrainian loess; (b) glacial loess produced by mountain glaciers, this would be most of the loess in China, and in Central Asia, material produced in the mountains of 'High Asia'; (c) desert loess produced by desert processes in deserts, i.e. the deposits in Africa and nearby, as described by Crouvi et al. (2010); (d) desert loess found in association with deserts but which has been stored in the desert region after material manufacture away from the desert. Smalley \& Derbyshire (1989), wrestling with these terminological problems suggested recognising type (a) as 'ice-sheet' loess, and types (b) and (d) as 'mountain' loess. A possibly awkward system which drew instant criticism (Yaalon, 1991). Yaalon was very much concerned with type (c) and felt that it should be recognised and given a proper place in the world of loess scholarship. A view which is, quite properly, maintained by 'desert' scholars (see Bullard \& Livingstone, 2009). De- sert scholars wish to give proper recognition to type (c) loess. Perhaps category (c) loess could be called 'Obruchev' loess, and category (d) loess might be termed 'Penck' loess. Of course, a cursory glance will reveal that types (b) and (d) loess are essentially the same. The great deposits of 'desert' loess (the large impressive deposits) have their origins, as Penck claimed, in the mountains.

What appeared to be the definitive experiment on the production of quartz silt by aeolian impact was carried out by Kuenen (1960), using an elaborate wind tunnel. He found that quartz silt was not produced by mutually impacting sand grains; a striking negative result. Whalley et al. (1982), using a much simpler experimental set-up managed to produce silt particles from impacting sand grains and theirs proved to be a much more interesting and significant result. The critical difference between the Kuenen and the Whalley et al. experiments was that the Whalley group used 'real' sand, whereas Kuenen used specially prepared crushed Brazil quartz. The Whalley sand was full of crystalline defects, the Kuenen sand was free from crystalline defects. It was a good demonstration of the critical role played by 'Moss defects' in quartz silt production. Perhaps the best demonstration of Moss defects in action was provided by O'Hara-Dhand et al. (reported by Smalley \& Markovic, 2018b); they abraded natural quartz sand in a modified ring-shear machine and noted the progression of the grinding process. The idea of using a ring-shear machine as a model glacier was proposed by Wright (1995) in her studies of glacial and desert loess. Wright was a member of the Whalley group and she sought (quite properly) to demonstrate the effectiveness of aeolian impacts. She used a Bromhead ring-shear machine in essentially its default mode and obtained a very modest product from 'glacial' grinding experiments. The machine was designed to conduct shear strength tests on clay soils and was not initially ideal for glacial model experiments. A slightly modified machine gave excellent glacial grinding results and demonstrated fairly convincingly the role of Moss defects in silt production (see Smalley \& Markovic, 2018b).

When the developed theory of glacial grinding was first proposed (Smalley 1966) it was believed that quartz sand grains were extremely hard and resistant to deformation- thus glacial grinding was the only natural force powerful enough. This argument in favour of glacial grinding was weakened by the realization that quartz sand grains contain crystalline defects which introduce weaknesses and promote breakage. Particle breakage by aeolian impact became more likely. 
The Whalley group linked the idea of impact breakage to the formation of the Chinese loess. Studies on the Chinese loess itself (e.g. Stevens et al., 2013; Li et al., 2018) have begun to indicate source areas in High Asia and start to show a clear source in the cold regions, rather than in the deserts. There is no doubt that sandy deserts produce fine airborne material (Stuut et al., 2010). But essentially it is fine silt $(\sim 3 \mu \mathrm{m})$ which can be transported in high suspension over long distances.

\section{Conclusions}

These are conclusions about desert loess embedded in some more general conclusions about the totality of the loess world.

Most loess material is formed by glacial action in cold regions of the world. Two types of glacial loess can be readily distinguished: loess associated with ice-sheets, e.g. much of the loess in North America, and loess associated with high, cold environments where mountain glaciers produce loess material.

The mountain loess is more sensitive to climatic fluctuations and hence delivers a superior record of climate variation and is a better indicator of Quaternary events. The mountain loess morphs into the desert loess- loess associated with deserts, like, for example, the Tajikistan loess. The long mountain loess sections are the best for chronostratigraphic studies. (see e.g. Fitzsimmons et al., 2018).

A modest amount of non-glacial loess exists on small areas. This tends to be material made in deserts in the classic Obruchev manner. Largely by particle impact, which, by and large, tends to produce material much smaller than the accepted loess size.

Adobe is loess material associated with deserts. Parna is loess material associated with deserts but the particles in parna are not primary mineral particles, as in classic loess, but clay mineral agglomerate particles made in dry lake beds. Much of the dust material blown out of the Sahara consists of clay mineral agglomerate particles from dry lake regions, but this long travel dust tends be of a much smaller particle size. This is small dust, in contrast to loessic material which is large dust.

Perhaps the critical problem really is a material one. Brewer (1968) wanted material aspects to be more important in the study of soil (and sediment) nature. In fact, in the case of adobe the essential material problem has not yet been properly recognised but a more widespread appreciation of the adobe reaction will allow progress to be made on this front.

\section{Afterword}

Smalley et al. (2016) proclaimed the importance of soil material and proposed that the concept was central to the study of soils. He was right, the nature of the material is paramount, and the formation of the material is paramount. And this means the formation of the actual units, the actual particles which comprise the deposit of loess or adobe or parna or any other desert soil/sediment.

Bullard \& Livingstone (2009, p. 630), referring to desert loess, wrote that:

"The conditions that lead to loess accumulation (summarised by Smith et al., 2002) are: first, atmospheric and ground conditions in the source area that are conducive to deflation of material that can be carried in suspension; second, a specific combination of atmospheric and ground conditions that encourage the preferential deposition of silts from all the particle sizes being carried by the wind."

A preliminary condition should be listed: silty material, suitable for the formation of loess deposits, should be produced by natural processes. This can then be deflated and lifted; recognize and understand the $\mathrm{P}, \mathrm{T}$, and $\mathrm{D}$ stages in the old event based description of the loess deposit forming process (see Smalley, 1966; Smalley \& Krinsley, 1978).

\section{Acknowledgements}

We thank many people for useful discussions and advice; in particular Claudio Vita-Finzi of UCL and the Natural History Museum, John Moss at the CSIRO research centre at Black Mountain, Bruce Butler during the WPWG Loess Commission fieldtrip, Tony Dare-Edwards at Wagga Wagga, Janet Wright, Jim Bowler and Dan Yaalon (who was referee for Smalley \& Vita-Finzi, 1968, and long term correspondent on desert loess).

\section{References}

Assallay, A.M., Rogers, C.D.F. \& Smalley, I.J., 1998. Silt:

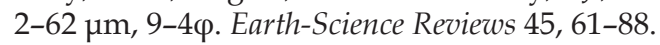

Brewer, R., 1964. Fabric and Mineral Analysis of Soils. Wiley, New York, 470 pp.

Brewer, R., 1968. Clay illuviation as a factor in particle-size differentiation in soil profiles. Transactions of $9^{\text {th }}$ International Congress of Soil Science 4, 489-499.

Bullard, J.E. \& Livingstone, I., 2009. Dust. [In:] A.J. Parsons \& A.D. Abrahams (Eds): Geomorphology of Desert Environments, Springer, Dordrecht, 629-655. 
Butler, B.E., 1956. Parna - an aeolian clay. Australian Journal of Science 18, 145-151 (reprinted in part in Loess Letter 54, 2004, www.loessletter.msu.edu.)

Crouvi, O., Amit, R., Enzel, Y. \& Gillespie, A.R., 2010. Active sand seas and the formation of desert loess. Quaternary Science Reviews 29, 2087-2098.

Crouvi, O., Enzel, Y., Ben-Dor, Y. \& Amit, R. (Eds), 2015. Atmospheric dust, dust deposits (loess) and soils in the Negev Desert: guidebook for the Batsheva de Rothschild Seminar on Atmospheric Dust, Dust Deposits (Loess) and Soils in Deserts and the Desert Fringe. Jerusalem \& Negev, Israel. Report GS1/22/2015.

Crouvi, O., Amit, R., Enzel, Y., Porat, N. \& Sandler, A., 2008. Sand dunes as a major proximal dust source for late Pleistocene loess in the Negev desert, Israel. Quaternary Research 70, 275-282.

Dare-Edwards, A.J., 1983. Loessic clays of south-eastern Australia. Loess Letter Supplement 2 (Dust mantles in Australia) 3-15.

Dare-Edwards, A.J., 1984. Aeolian clay deposits of south-eastern Australia: parna or loessic clay? Tranactions of the Institution of British Geographers 9, 337-344.

Fitzsimmons, K.E., Sprafke, T., Zielhofer, C., Gunter, C., Deom, J.-M., Sala, R. \& Iovita, R., 2018. Loess accumulation in the Tien Shan piedmont: implications for palaeoenvironmental change in arid Central Asia. Quaternary International 469A, 30-43.

Greeley, R. \& Williams, S.H., 1994. Dust deposits on Mars; the 'parna' analog. Icarus 110, 165-177.

Haberlah, D., 2007. A call for Australian loess. Area 39, 224-229.

Haberlah, D., 2008. Response to Smalley's discussion of 'A call for Australian loess'. Area 40, 135-136.

Heller, F. \& Liu, T.S., 1982. Magnetostratigraphical dating of loess deposits in China. Nature 300, 431-433.

Jefferson, I., Rosenbaum, M. \& Smalley, I.J., 2002. Mercia Mudstone as a Triassic Aeolian desert sediment. Mercian Geologist 15, 157-162.

Keilhack, K., 1920. Das Ratsel der Loessbildung. Zeitschrift der Deutschen Geologische Gesellschaft 72, 146-161.

Kuenen, Ph.H., 1960. Experimental abrasion 4: eolian action. Journal of Geology 68, 427-449.

Li, L., Chen, J., Chen, Y., Hedding, D.W., Li, T., Li, L., Liu, X., Zeng, F., Wu, W., Zhao, L. \& Li, G., 2018. Uranium isotopic constraints on the provenance of dust on the Chinese Loess Plateau. Geology https://doi. org/10.1130/G45130.1

Mavlyanov, G.A., 1958. Genetical types of loesses and loesslike rocks in the central and southern parts of Central Asia and their engineering-geological properties. Izdatelstvo Akademii Nauk Uzbekistanskovo SSSR, Tashkent, 609 pp. (in Russian).

McLaren, S.M., Svircev, Z., O'Hara-Dhand, K., Heneberg, P. \& Smalley, I.J., 2014. Loess and bee-eaters II: The 'loess' of North Africa and the nesting behaviour of the Northern Carmine Bee-eater (Merops rubicus Gmelin 1788). Quaternary International 334/5, 112-118.

Merzbacher, G., 1913. Die Frage der Entstehung des Lösses. Petermanns Geographische Mitteilungen 59, 16-130.
Obruchev, V.A., 1911. The question of the origin of loess in defense of the aeolian hypothesis. Izvestia Tomskovo Tekhnologiceskovo Instituta 33 (in Russian).

O'Hara-Dhand, K., Taylor, R.L.S., Smalley, I.J., Krinsley, D.H. \& Vita-Finzi, C., 2010. Loess and dust on Earth and Mars: particle generation by impact mechanisms. Open Geosciences 2, 45-51.

Ojha, L., Lewis, K., Karunatillake, S. \& Schmidt, M., 2018. The Medusae Fossae formation as the single largest source of dust on Mars. Nature Communications 9, 2867.

Penck, A., 1909. Die Morphologie der Wüsten. Geographische Zeitschrift 15, 545-558.

Penck, A., 1930. Central Asia. Geographical Journal 76, 477-487.

Rahmani, A., Hazzab, A. \& Aimer, H., 2018. Identification et classification geotechnique du Loess de Ghardaia (Sud Algerien). Algerian Journal of Arid Environments 8, 88-103.

Rogers, C.D.F. \& Smalley, I.J., 1995. The adobe reaction and the use of loess mud in construction. Engineering Geology 40, 137-138.

Russel, R.J., 1944. Lower Mississippi valley loess. GSA Bulletin 55, 1-40.

Scheidig, A., 1934. Der Löß und seine geotechnischen Eigenschaften. Dresden, Leipzig.

Smalley, I.J., 1966. The properties of glacial loess and the formation of loess deposits. Journal of Sedimentary Research 36, 669-676.

Smalley, I.J. (Ed.), 1975. Loess Lithology and Genesis. Benchmark Papers in Geology 26. Dowden Hutchinson Ross, Stroudsburg 429 pp.

Smalley, I.J., 2008. A call for Australian loess: discussion. Area 40, 133-134.

Smalley, I.J. \& Derbyshire, E., 1989. The definition of icesheet and mountain loess. Area 22, 300-301.

Smalley, I.J. \& Krinsley, D.H., 1978. Loess deposits associated with deserts. Catena 5, 53-66.

Smalley, I.J. \& Krinsley, D.H., 1979. Eolian sedimentation on Earth and Mars: some comparisons. Icarus 40, 276-288.

Smalley, I.J. \& Markovic, S.B., 2018a. Four loess pioneers: Ch. Lyell, F. von Richthofen, V.A. Obruchev, L.S. Berg. Quaternary International 469A, 4-10.

Smalley, I.J. \& Markovic, S.B., 2018b. Controls on the nature of loess particles and the formation of loess deposits. Quaternary International doi: org/10.1016/j. quaint.2017.08.021.

Smalley, I.J. \& Vita-Finzi, C., 1968. The formation of fine particles in sandy deserts and the nature of 'desert' loess. Journal of Sedimentary Research 38, 766-774.

Smalley, I.J., McLaren, S. \& O'Hara-Dhand, K., 2016. Loess and bee eaters IV: distribution of the Rainbowbird (Merops ornatus Latham 1801) in Australia. Quaternary International 399, 240-245.

Smalley, I.J., O'Hara-Dhand, K., McLaren, S., Svircev, Z. \& Nugent, H., 2012. Loess and bee-eaters I: Ground properties affecting the nesting behaviour of European bee-eaters (Merops apiaster L 1758) in loess deposits. Quaternary International 296, 220-226. 
Stevens, T., Carter, A., Watson, T.P., Vermeesch, P., Ando, S., Bird, A.F., Lu, H., Garzanti, E., Cottam, M.A. \& Sevastjanova, I., 2013. Genetic linkage between the Yellow River, the Mu Us desert and the Chinese loess plateau. Quaternary Science Reviews 78, 355-368.

Stuut, J.-B., Smalley, I.J. \& O'Hara-Dhand, K. 2009. Aeolian dust in Europe: African sources and European deposits. Quaternary International 198, 234-245.

Sun, J. \& Windley, B.F., 2015. Onset of aridification by 34 Ma across the Eocene-Oligocene transition in Central Asia. Geology 43, 1015-1018.

Tsoar, H. \& Pye, K., 1987. Dust transport and the question of desert loess formation. Sedimentology 34, 139-153.

Whalley, W.B., Marshall, J.R. \& Smith, B., 1982. Origin of desert loess from some experimental observations. Nature 300, 433-435.

Wright, J.S., 1995. Glacial comminution of quartz sand grains and the production of loessic silt: a simulation study. Quaternary Science Reviews 14, 669-680.

Wright, J.S., 2001a. 'Desert' loess versus 'glacial' loess: quartz silt formation, source areas and sediment pathways in the formation of loess deposits. Geomorphology 36, 231-256.
Wright, J.S., 2001b. Making loess-sized quartz silt: data from laboratory simulations and implications for sediment transport pathways and the formation of 'desert' loess deposits associated with the Sahara. Quaternary International 76, 7-19.

Wright, J.S., 2007. An overview of the role of weathering in the production of quartz silt. Sedimentary Geology 202, 337-351.

Wright, J.S. \& Smith, B., 1993. Fluvial comminution and the production of loess-sized quartz silt: a simulation study. Geografiska Annaler, Physical Geography 75, 25-34.

Wright, J.S., Smith, B. \& Whalley, W.B., 1998. Mechanisms of loess-sized quartz silt production and their relative effectiveness: laboratory simulations. Geomorphology 23, 15-34.

Yaalon, D.H., 1969. Origin of desert loess. Etudes Quaternaire du Monde, Proceedings of the $8^{\text {th }}$ INQUA Congress Paris, 2, 755 (reprinted in Smalley, 1975).

Yaalon, D.H., 1991. Mountain loess is not a suitable term. Area 23, 255-256.

Manuscript received 4 November 2018 Revision accepted 3 March 2019 